\title{
Illiberal Trends and Anti-EU Politics in East Central Europe: Major Findings and Avenues for Future Research
}

\author{
Astrid Lorenz and Lisa H. Anders
}

\section{INTRODUCTION}

When, in April 2020, the Court of Justice of the European Union (CJEU) ruled that Hungary, Poland and the Czech Republic had violated EU law by ignoring the refugee relocation quota, the reactions did not take long and followed the pattern typical of all recent confrontations between East Central European governments and the "rest of Europe".

On the one side, the Hungarian Minister of Justice Judit Varga commented that the relocation scheme was "dead" anyway and found it shocking that only the three East Central European countries were sentenced while almost no EU member state had fully implemented the 2015 quota decisions (Stevis-Gridneff and Pronczuk 2020; Ministry of Justice 2020; Varga 2020). The Czech Prime Minister Andrej Babiš and

\section{A. Lorenz $(\bowtie) \cdot$ L. H. Anders}

Institute of Political Science, Leipzig University, Leipzig, Germany e-mail: astrid.lorenz@uni-leipzig.de

L. H. Anders

e-mail: 1.anders@uni-leipzig.de

(C) The Author(s) 2021

A. Lorenz and L. H. Anders (eds.), Illiberal Trends and Anti-EU Politics in East Central Europe, Palgrave Studies in European Union Politics, https://doi.org/10.1007/978-3-030-54674-8_14 
his Interior Minister Jan Hamáček stated that the ruling was "not that important". Babis insisted that Czechia "will not accept any migrants" and concluded that "the quota system was cancelled mainly thanks to us" (Stevis-Gridneff and Pronczuk 2020; Prague Morning 2020). The Polish Minister Zbigniew Ziobro criticised that "some EU institutions are completely detached from reality" and proceeded that "Poland was right not to accept refugees" as it had to defend its "sovereignty against the foreign culture of Islam that they wanted to impose" on the country even though the European treaties would not oblige member states to accept refugee quotas (Tilles 2020). Prime Minister Mateusz Morawiecki added that Poland definitely will not accept any refugees (Tilles 2020).

On the other side, when recommending the ruling to the court, CJEU Advocate General Eleanor Sharpston drew similarly far-reaching conclusions and declared that disregarding EU obligations "is a dangerous first step towards the breakdown of the orderly and structured society governed by the rule of law". She continued that the "principle of solidarity necessarily sometimes implies accepting burden-sharing" (Janicek et al. 2019). When the CJEU issued the ruling, the President of the European Commission Ursula von der Leyen stressed its importance. Contradicting the ECE government officials, she underlined that "all member states were required to participate in a temporary relocation scheme". The court's decision, she concluded, "will give us guidance to the future" (TVN24 2020).

Once again, these statements reproduced the general scheme of the public conflicts between EU officials and the ECE governments: the latter accuse the EU of applying double standards, of stretching EU law to promote left-liberal values, of instrumentalising courts for politically motivated rulings and of imposing its particular interpretation of EU law on member states against the will of their people. In their eyes, they are the true guardians of European values and European democracy. In the meantime, EU actors insist on their interpretation of EU law and the legitimacy of the Union's decision-making procedures, and they criticise the ECE countries for destroying the rule of law as such and reproach them for lacking European solidarity while benefiting from generous EU financial aid.

The list of such conflicts is as long as the list of questions emerging from them: Are East Central European member states really increasingly or even generally unwilling to accept EU decisions and to adhere to European law? Do these countries really have less solidarity? Are the anti-EU 
rhetoric and politics in ECE systematically related to the growing illiberal measures against counter-majoritarian institutions in the region? Do the governing parties follow their own ideological agenda when confronting the EU and liberal values, or do they respond to voters' preferences? And do the national publics in the four states share common perceptions of the EU and illiberalism or are regional commonalities less pronounced than politicians, media coverage and stereotype conflict narrations suggest?

To address these questions around the domestic causes and context conditions of illiberalism and anti-EU politics, the volume comprises qualitative and quantitative contributions from scholars of different disciplines with broad expertise in East Central European politics and comparative European sociology. Translating the aforementioned questions into more general tasks, the chapters aimed to explore the national contexts of illiberal trends and anti-EU politics, compare and contrast the dynamics in all four EU member states and analyse, especially with regard to the societal roots, if the differences between East and West are as sharp as often claimed. As laid out in the introduction of this volume, the overall aim was to capture the different facets of the illiberal trends and anti-EU politics in ECE countries to arrive at a more encompassing understanding of these phenomena. This concluding chapter summarises and discusses key findings of the volume as well as their implications for future research.

\section{Individual Chapter Findings AND Cross-Chapter LINKAgES}

The first part of the book dealt with the societal background of illiberal trends and anti-EU politics. The chapters show that the four states are quite similar in some aspects but clearly different in others. The quantitative analyses found no empirical evidence of a general lack of European solidarity (as suggested by the persistent refusal of the Visegrád governments to participate in the resettlement system). Nor did they provide proof that support for the EU would be particularly low in ECE countries. This is consistent with the observation made in our introduction to the book that the share of people who trust the EU either exceeds the EU average (Poland, Slovakia) or is comparably high (Czech Republic, Hungary). The study on anti-Muslim attitudes uncovered deviations from the "rest of Europe" while the general linkage between anti-Muslim attitudes and Euroscepticism is present all over Europe. 
Based on the European Elections studies data from 2004 to 2019, Lars Vogel shows in Chapter 2 that the share of Eurosceptics, especially of hard Eurosceptics, is rather low in ECE. Despite the EU financial and migration crises, diffuse support for the EU has even increased within the last years while it decreased in the remaining EU countries. Policy-specific support, in contrast, is rather volatile. It decreased significantly in all ECE countries and also in the average of the other EU countries in 2014 and then rose again in 2019. Cultural issues, e.g. nationalist orientations or conceptions of democracy, were only in two of the ECE countries statistically related to public Euroscepticism, namely, in Poland and Hungary. Differences between countries are also apparent concerning the factors that explain Euroscepticism. The analysis of Euroscepticism determinants reveals country-specific rather than regional patterns, indicating that citizens base their evaluation of European integration on country-specific criteria.

In Chapter 3, Gert Pickel and Cemal Öztürk demonstrate that in many EU countries, voters of right-wing populist parties are the main bearers of the aforementioned linkage between anti-Muslim attitudes and Euroscepticism. They often support a Muslim ban and perceive that European unification has gone too far. In Eastern Europe, however, anti-Muslim sentiments are generally more widespread and shared by both voters of right-wing populist and mainstream parties. The authors highlight the risk of governments instrumentalising anti-Muslim attitudes to mobilise against the EU by claiming that it orchestrates a "Muslim invasion". Their data demonstrate that even if governments refrain from such campaigns, a liberal-universalist European asylum and migration policy obviously collides with the deeply rooted Islamophobia of the electorate in ECE and probably results in EU criticism in this sphere.

Article 2 of the Treaty on European Union stipulates solidarity as one of the founding principles of European societies. Analysing citizens' attitudes towards European solidarity, Florian K. Kley and Holger Lengfeld show that East Central Europe does not generally stand out from patterns in other EU countries. As Chapter 4 reveals, a majority of Slovak, Hungarian and Polish people support the idea of financial assistance for indebted EU countries as well as redistributive measures among EU member states. As in Southern countries, levels of support for an EU-wide reduction of territorial disparities in the three ECE countries even exceed the support of such measures for reducing differences within the country. The authors attribute this to the rational calculation of the 
respondents as ECE countries might benefit from such a redistribution policy. All in all, the chapter reveals that the widespread assumption that ECE countries generally lack solidarity is not substantiated. Moreover, the approval of the ideas of solidarity differs across East Central European countries. This finding indicates that regional affiliation is not a relevant category for explaining attitudes towards European solidarity.

Taken together, the contributions of the first part of the book show that, on average, people in ECE are not more Eurosceptic than people in other member states. It seems, however, that the majority of citizens in the region have an instrumental understanding of European policymaking. According to such an understanding, European policies should serve the will and fit the values of the (national) majority. The chapters suggest that people in ECE countries accept further integration when expected gains are high. Accordingly, redistributive measures, which potentially benefit these countries, would generally be supported by a majority of people in East Central Europe. In contrast, any plan to further integrate asylum and migration policy in a liberal-universalist version will probably cause critique, while-just as a fictive scenario-a common European walling-off strategy towards Muslim migrants combined with a less restrictive policy towards non-Muslims might find support. As has been shown, the majority of people in East Central Europe are hostile towards Muslims and politicians exploit this deeply rooted Islamophobia to stir anti-EU sentiments. The instrumental approach to EU policies and institutions, therefore, is not only related to financial gains but also to how they fit to perceived values and attitudes.

The contributions of the second part of the volume explore the complex domestic processes around illiberal and anti-EU politics in East Central Europe. In contrast to the first part, they focus more on the agents of the current illiberal trends in the region, analysing the illiberal rhetoric and practice of politicians, parties and their linkage to voters, and the politicisation of administrations. They thereby show that illiberal trends are neither uniform nor determined by fixed regional characteristics but initiated and realised by domestic actors with diverging, sometimes flexible positions in varying political configurations. Despite some similarities, such as the politicisation of certain policies and attempts to increase executive power at the expense of the legislature, the countries do not form a coherent group with respect to illiberalism and relations with the EU. Often, illiberalism is not rooted in a strict and manifest illiberal agenda but can be attributed to pragmatic attempts to secure certain 
policy goals or to generate electoral support by addressing voters' attitudes. In other cases, rhetoric and action do only partly overlap and illiberal rhetoric has little impact on actual policy.

In Chapter 5, Vratislav Havlík and Vít Hloušek shed light on the various facets of illiberalism in East Central Europe by studying the different ideologies underpinning the illiberal rhetoric and by comparing how ruling parties put more or less pronounced illiberal ideologies into political practice. Fidesz (Hungary) is assessed as having a flexible illiberal doctrine and PiS (Poland) a coherent illiberal ideology. In contrast, ANO (Czech Republic) and SMER (Slovakia) do not have an explicitly illiberal programme, meaning that their illiberal stances are a result of pragmatic choices. With regard to illiberal practices, the contribution shows that in all four countries, the ruling parties strengthened the executives while eroding checks and balances. ${ }^{1}$ Concerning the other dimensions of illiberalism (e.g. measures towards media, courts and NGOs) practices vary. This clearly demonstrates that there is no coherent pattern of illiberalism and illiberal political practice in East Central Europe.

Focusing on Hungary and the Czech Republic, Chapter 6 by Paula Beger provides new insights into the politicisation and compliance of asylum and migration policy-a policy field which induced massive changes in party systems all over Europe. As the contribution shows, in both countries, the policy was shaped by pre-accession Europeanisation, when national administrations adopted EU standards in a technical and uncontested downloading process. Not until 2015 did questions of asylum and migration become politicised in the partisan and public sphere of both countries. Then, the comparable levels of politicisation in the two countries yielded different effects. In Hungary, the Fidesz-KDNP government exerted influence on the asylum-related administration which resulted in decreased compliance with EU law. The Czech administration, in contrast, has remained rather unpoliticised and therefore continued to comply with EU law. This suggests that an administration can-if it is able to act autonomously-secure the implementation of EU policies even if domestic governments are at loggerheads with the EU.

In Chapter 7, Michał Dulak also exploits the advantages of case study methodology. He delves into the details of Polish party politics from

\footnotetext{
${ }^{1}$ Another similarity is that in none of the four countries did the authors detect politically motivated interference with private property and the autonomy of proprietors' actions in the economy expropriation measures, which is one of their ten indicators of illiberalism.
} 
2004 to 2019 to explain the phenomenon that an increasingly coherent illiberal party programme must not necessarily lead to programmatic deEuropeanisation. In fact, the manifestos of the main governing party PiS did not contain calls to leave the EU or other signs of hard Euroscepticism (the refusal of introducing the Euro currency is the only exception). This strategy is explained by PiS's intention to be responsive to the different positions on EU issues among its electorate. While the main opposition party PO also took a pro-European position, PiS declared itself as being "Euro-realist". This self-positioning of PiS in EU issues deviates from the observation by Pickel and Öztürk in that the party has not-at least in its programme-tied its restrictive preferences in asylum policy with general Euroscepticism. However, it is in line with the observations made by Vogel, Kley and Lengfeld regarding the general EU support which is partly based on instrumental or benefit-oriented calculations.

In another qualitative study, Petra Guasti illustrates the illiberal backlash against universal rights in the Czech Republic and Slovakia. Her contribution shows that the transnational legal context is marked by a liberal development and pro-universal rights, including LGBT rights and gender equality. This influences domestic opportunity structures, but it cannot guarantee the self-enforcement of these rights. Many domestic actors from the radical right to radicalised mainstream politicians are increasingly adopting a populist socially conservative rhetoric around the notion of sovereignty and reject attempts to increase minority rights as being imposed by the EU or the Council of Europe. This contributes to domestic polarisation. Despite similar levels of domestic polarisation in the Czech Republic and Slovakia, European norms concerning LGBT rights and the Istanbul Convention were accommodated to different degrees. Depending on the configuration of domestic party competition, mainstream parties partly transposed norms but resisted further accommodation due to fear of polarisation (Czech Republic) or, in a more religious society, radicalised to fend off radical right challengers (Slovakia).

Thus, in summary, it depends on strategies of domestic politicians if and how far the opportunities of the European legal framework are used in the national policy arena. Also, in the light of the findings of the first part of the book, this suggests that perceived deviations of European policies from habits and traditions of the domestic majority can result in anti-EU polarisation, but this does not automatically have to be the case. It depends on individual cost-benefit calculations of political actors within a given domestic context. Mainstream parties can refuse more 
liberal-universalist policies or even radicalise, not because of a respective ideology, but in order to avoid polarisation over-what is interpreted by large parts of the public as-Europeanisation. Ideology-driven illiberalism, in contrast, does not necessarily entail a strict anti-EU course. As a result, there is no general lack of compliance or increased general anti-EU programme irrespective of growing illiberalism.

The contributions of the third part of the volume focus on the reactions to illiberal trends and EU-critical politics. All of them devote special attention to the interplay between actors at the European and the domestic level. Collectively, the Chapters 9 through 11 illustrate the various difficulties surrounding the EU's tools against illiberal backsliding. Instead of solving the rule of law conflicts at hand, they stirred an ever harsher dispute. In a more or less ritualised manner, EU actors strongly criticise the erosion of the rule of law while the Hungarian and the Polish governments stress the lack of a generally accepted definition of these terms. Essentially, all these disputes evolve around the diverging cultures, different political philosophies and different approaches to balance the (domestic) rule by the people and the (supranational) rule of law. Since many of the EU's instruments against illiberal backsliding are based on regular dialogue (Article 7 procedure, the Rule of law mechanism and infringement procedures), they currently seem to exacerbate rather than improve the situation.

In an important contribution, Attila Vincze critically discusses what he calls the "common misperceptions" in the debate on the rule of law in Hungary and Poland and also illustrates how illiberal governments can exploit them to justify their course of action. Orbán, for instance, can easily accuse the EU for applying double standards as EU actors did not claim any Article 2 violations when previous Hungarian governments meddled with political institutions before 2010. Moreover, as Article 2 TEU contains arbitrary and contested terms, some illiberal measures in ECE are not formally breaching EU law but still fall within the sphere of different interpretation. As values are declared but not operationalised, they give-counterintuitively-ground for value relativism. Against this backdrop, many EU measures to redress backsliding turned out to be illsuited. The targeted governments could easily frame them as primarily political attacks. The Union, Vincze therefore concludes, should focus on using competences, powers and procedures which are immune to the Hungarian government's sophistry. 
To complement this general assessment of the rule of law debate with an empirical analysis, Lisa H. Anders and Sonja Priebus investigate the suitability of infringement procedures to enforce the EU's foundational values. Their study reveals that rule of law problems were clearly addressed as the Commission explicitly referred to fundamental democratic prerequisites in most of the cases. The Commission, therefore, seems well aware that a mere reference to secondary law invites targeted governments to reject the rule of law relevance of the infringement procedures. Thus, the conventional view that the procedures lead to a miscategorisation of the rule of law problems seems unwarranted. Nevertheless, the procedures did not help to solve or to depoliticise the conflicts. On the contrary, the relations worsened and the Hungarian government increasingly exploited the infringement procedures to blame the EU for interfering in domestic affairs.

In the light of these apparent shortcomings of existing instruments against illiberal backsliding, Claudia-Y. Matthes focuses on a hitherto understudied aspect, namely, the idea to complement the EU's topdown tool-box with bottom-up approaches including civil society actors. In Chapter 9, she investigates for the case of Poland how civil society actors can hinge for the Commission into Polish society and, in doing so, contribute to safeguarding democracy and rule of law from below. As the chapter demonstrates, the opportunity structures for liberal civil society organisations are not too bright, especially since PiS has started to target them by restricting assembly rights and changing the mode of financing the NGO sector. Despite these measures, the Polish civil society organisations managed to provide information on illiberal backsliding and to keep the topic on the domestic and European agenda.

Taken together, the three contributions show that the EU's conventional top-down as well as newer bottom-up approaches could not redress the illiberal trends in Hungary and Poland so far. As the EU's foundational values are listed in Article 2 TEU but not further specified, governments can rightly argue that the meaning of the terms is contested and they often use this argument to frame EU actors' criticism concerning the rule of law as political attacks violating the rule of treating all member states equally. The role of civil society organisations in the struggles with the EU is also twofold. Actors fighting for liberal values are often perceived (by a large part of the domestic public) or labelled (by the national government) as EU-driven. Thus, assisting pro-democratic and liberal forces can also have unintended negative effects if domestic actors 
point to the support of the EU to refer to the pro-democratic and liberal forces as "foreign agents" to mobilise against the NGO sector.

The concluding fourth part of the book addresses conceptual questions and broadens the perspective beyond the Visegrád region. The contributions discuss various terms and concepts to capture the deterioration of democracy and the rule of law, and they remind us that illiberal trends and anti-EU politics are not confined to ECE countries.

In Chapter 12, Luca Tomini and Seda Gürkan focus on the relation between the decline of democracy and de-Europeanisation. Their contribution argues that the term "illiberal backsliding" actually does not capture the de-democratisation processes properly as it implies that democracies revert to something that existed in the past. Against this background, the broader term of autocratisation might be more appropriate. Based on a comparison of countries with varying degrees of autocratisation and de-Europeanisation, the contribution furthermore shows that autocratisation usually precedes de-Europeanisation. Thus, de-Europeanisation scholars should focus primarily on domestic level explanatory factors; not only that, but the domestic agents especially deserve closer inspection as well. This is in line with the volume's approach and also corroborates the finding of several chapters that democratic development cannot be taken for granted even if countries have oriented themselves towards the EU. Instead, domestic factors are highly relevant to the practice of democracy and its sustainability.

As Ireneusz Paweł Karolewski aptly describes, long-established democracies too can fall prey to populist politics and attacks on liberal democratic institutions. Against this backdrop, he reasons that we need a general approach to theorising backsliding. Drawing on the literature on democratic transitions and current research on illiberalism, he therefore develops a three-dimensional heuristic for future research on this topic. It puts the spotlight on the role of the citizens, types of state capture, the erosion of liberal democratic practices and their aggregate effects. As the author highlights, democratic backsliding does not necessarily lead to a fully fledged authoritarian system but can also result in hybrid regimes. His heuristic is in line with the outline of this book and also reaffirms the suitability of a more encompassing analysis of illiberal trends. 


\section{Conclusions, Open Questions ANd Future Research}

What are the main findings of the volume and what are avenues for future research? Addressing these two questions, this section briefly presents selected key findings and promising paths for future studies. The structure follows the outline of the book, starting from societal issues, proceeding with politics matters, continuing with political reactions to illiberal and anti-EU politics and finishing with theoretical contextualisation.

Democracy rests on citizens. They need to participate in democratic decision-making and generally support the political system. In this vein, every liberal political entity depends on supportive beliefs that it cannot enforce without giving up the logic of freedom (Böckenförde 1976). The $\mathrm{EU}$ is no exception. As the contributions of the first part of the volume show, the strong focus on conflicts between the EU and East Central Europe obscures the fact that the people generally support the EU and are not more Eurosceptic than people in other member states. At the same time, the Visegrád governments' fierce opposition against the European asylum and migration policy is backed by large parts of the populations because anti-Muslim attitudes are widespread in the region. Hence, the appropriate addressees of the policy-conflicts between the EU and ECE are not only the governments of the respective member states but also the citizens. To our view, two aspects of the citizens' perspectives on illiberalism and the EU deserve special attention in future research.

Firstly, studies should address why people came to support illiberalism and how personal experiences influence their EU-related imaginations and attitudes. Thus, we need more research on the micro-foundations of individual perceptions and cognitive maps of (il)liberal democracy, EU policies and the EU as a whole. As mentioned in Chapter 1, illiberal trends are often marked by an increasing mobilisation along the socialcultural axis of political contestation (Havlík 2019; Vachudova 2019; Chapters 3 and 8). Many studies therefore highlighted changes in the distribution of political preferences and the increased importance of an axis of party competition that spans between libertarian and authoritarian sociocultural positions (Kitschelt 2003, p. 6f.) or a new cleavage between communitarian and cosmopolitan views (e.g. de Wilde et al. 2019). As we know, such phenomena, irrespectively of some similarities, can have different regional causes (Manow 2019, pp. 38ff.; Bustikova and Kitschelt 2009). In ECE, both the "cultural counter-revolution" (Krekó 
and Enyedi 2018, p. 45) and the regular rails against the EU intrusion are at least partly motivated by the desire of citizens to emancipate themselves from perceived "Western" demands and expectations of how democracy and politics are done right.

We want to highlight the importance of studies on individual processes of position-(re)building on democracy and EU issues, and on how it reflects one's own experience with transformation and EU membership. In East Central Europe, most of the citizens have not been engaged in politics since the early 1990s. There are two main reasons for that: they had not been socialised to individual autonomous political activism in the ancient régime and they faced the high demands of re-organising their personal life. Just like the political and economic systems (Offe 1994), citizens faced complex individual transitions. Thus, popular involvement in democracy (i.e. civic engagement and political participation beyond voting in elections) remained low (Bernhagen and Marsh 2007). This, in turn, fostered alienation processes between citizens and decision-makers. Some of the statements in European public opinion polls and voting behaviour seem to be inspired by the desire of citizens to teach decision-makers a lesson they will not forget and to correct their (perceived) lack of responsiveness. For these reasons, we suggest that future research on the individual attitudes on (il)liberal democracy, the EU and EU policies should not only consider the citizens' present sociodemographic features ${ }^{2}$ but also try to trace the long-term effects of individual transformation and EU enlargement experiences on current political views. At the same time, it would be interesting to know more about citizens' individual weighing up of normative and rationalist motivations regarding the EU. Questions for further investigations could also be if individual opinions articulated in polls reflect manifest and coherent individual mindsets or if they are inconsistent and in flux.

Secondly, further empirical research is needed to explore what particular form of European democracy people prefer. This question refers to normative attitudes towards democracy (liberal-universalist vs communitarian-utilitarianist concepts) and its particular functioning in a multi-level polity. While the Eurobarometer, the European Values Study

\footnotetext{
${ }^{2}$ In fact, there is growing and valuable research on these issues (see, for instance, Kaltwasser and van Hauwaert 2020, who analyse the individual sociodemographic characteristics of populist citizens).
} 
and other cross-national polls already provide valuable insights into attitudes towards European integration and other selected issues, it would be interesting and relevant for the Union's future to capture the citizens' preferences towards the particular constitutional structure of the EU: from unitarian republic up to a decentral Union of nation-states. Several contributions in this volume inform about the party positions concerning these aspects. But since most of the citizens are not organised in parties and voter turnout is rather low, EU- and democracy-related preferences cannot only be measured simply by looking at party preferences. Thus, more grass-root sociological research is needed to answer the questions (see, for promising approaches along these lines, Hurrelmann et al. 2015).

The contributions in the second part of the volume show in many ways that domestic political actors often do not follow a uniform illiberal agenda or a coherent anti-EU strategy. Besides, East Central European actors do not "make trouble" in all institutional questions or policy fields. Instead, they were interested in securing national veto capacity or regaining sovereignty in a limited set of issues. To date, these are the definition of (national) identity, citizenship, minority rights which all refer also to migration policy, as well as democracy and rule of law. These issues are highly politicised but the strong politicisation, also when combined with explicit anti-EU rhetoric, does not generally lead to non-compliance with EU-law. Obviously, there are differences between rhetoric and practice. Against this backdrop, we suggest that future research should include the following domains:

Firstly, the anti-EU rhetoric-its nuances and changes over time deserve closer inspection. As recent publications revealed, governments can simultaneously support the EU as an organisation, openly rail against its policies (or some of them) by arguing that EU institutions are dominated by liberal-leftist actors or ruled by George Soros and present themselves as the true Europeans (Mos 2020). It thus seems that we need a more fine-grained understanding of how politicians (and also the media) in ECE countries frame the EU and EU policies. It should also be explored in more detail how far the governments' anti-EU rhetoric reflects their responsiveness to attitudes that are widespread among the population and how far it is a means to activate and manipulate the citizens' latent attitudes to get their support. The contributions in this book provide evidence for both directions of influence, but more information to qualify the weight of both would be valuable. As for the 
temporal dimension of politicising EU-related issues, it might also be discussed if the public contestation of these issues represents, at least to some extent, a kind of "normalisation" or, to use a less normative term, a revitalisation of political conflict on EU matters. ${ }^{3}$ As Chapter 6 and countless Europeanisation studies have shown, before EU-accession, the often newly founded political parties did not yet have elaborated positions on EU issues. Combined with the EU conditionality policy, this resulted in a technocratic top-down transposition of EU norms that was not accompanied by a broad domestic political debate. But public debate and conflicts on the justification of public policies are the main ingredients of democracy. Democratic choice requires visible alternatives.

Secondly, future studies on the causes and practices of illiberalism and the strained relations between the EU and East Central Europe should further explore the relationship between policy-makers and two types of actors: administrations and courts. To date, the attempts to diminish the powers of administrations and courts are in most cases explicitly and implicitly explained with reference to their counter-majoritarian function. Other potential explanations that would go beyond the mere idea of power accumulation have received less attention. Future research, therefore, should explore if attempts to weaken administrations and courts are also caused by diverging understandings of democracy and rule of law ${ }^{4}$ and the intention to revise former governments' patronage policies or to block administrative officials' and judges' involvement into informal clientelistic networks. This might also explain why people do not oppose curtailing the administrations' room of discretion and support, like in the Czech Republic, a political course to improve "state efficiency". In the pre-accession phase and shortly thereafter, the role of national administrations for implementing EU law and public sector reforms received much scholarly attention (e.g. Zubek and Goetz 2010; Meyer-Sahling 2009; Ágh 2002; Dimitrova 2005). Processes within the administrations and their relationship vis-à-vis the political majorities after 2004, in turn, were

\footnotetext{
${ }^{3}$ Pickel (2009) proposes the term "revitalisation" as an alternative to "ormalisation" in his study on religiosity. The term "consolidation" of democracy also implies political competition and thus political conflicts, albeit within the "rules of the game" (Linz and Stepan 1996, p. 5f.; Merkel 1998).

${ }^{4}$ For historical legacies, see, e.g., Miklóssy (2018), Meyer-Sahling (2009) and Bos and Pócza (2014).
} 
covered to a lower degree. Early on, studies demonstrated the potential of such studies for better understanding domestic political tectonics (Grzymała-Busse 2003) and also recent analyses have suggested exploring the role of public administrations in backsliding processes (Bauer and Becker 2020).

The same is true for courts. In present publications, they are often almost exclusively referred to as targets of political restrictions. Like administrations, domestic courts are able to stop illiberal practices. Besides, they contribute to establishing a European legal framework by judicial interpretation (e.g. Thym 2017; Blauberger and Kelemen 2016; Jakab and Kochenov 2017). To do so, they can refer questions of EU law to the European Court and they can, to a higher or lower extent, refer to European law in their interpretation. The role of courts as "engines of integration" has often been described (Alter 2001). Due to the EU's “over-constitutionalisation" (Grimm 2015), rights especially have been "developed exclusively in the inner judicial-legal sphere" (Schmidt 2017, p. 18). Such dominance of non-majoritarian decisionmaking runs the danger of weakening political "voice". But "without sufficient backing by societal actors, rights cannot drive societal change" (Schmidt 2017, p. 18). Possible questions for further reflection therefore could be whether it is the courts' relevance for these aspects that motivates governments to limit their autonomy or whether there are also other domestic causes for such measures, e.g. judges' activism during transformation (e.g. Pospísil 2020). ${ }^{5}$

Part three of the book showed that, so far, the EU's tools against illiberal backsliding could not dissuade the targeted governments from their controversial reforms. Similar to the disputes on the asylum policies presented above, the conflicts on the EU's foundational values are increasingly staged and perceived as a clash of cultures. They have become a symbol of fighting for the right to determine rights while no side is willing to compromise. Against this background, we suggest further research on the institutional design of sustainable mechanisms of conflict accommodation and potential ways for achieving political agreement in constitutional issues.

\footnotetext{
5 To be clear, such research is not intended to somehow "excuse" illiberal measures or to identify the attacked institutions as the "true causes" of illiberalism but to explain the ramified roots of the emergence of illiberalism and why it is supported by parts of the opposition and citizens.
} 
Future research should, firstly, investigate how instruments can be deployed or designed to prevent the impression of double standards. As the contributions in part three of the book revealed and as also the European Commission (2019) underlines, an even-handed application of EU law in all member states is crucial to avoid the impression of unequal treatment of East and West European member states, which can easily be exploited to rail against the EU's politically motivated interference in domestic affairs. Some recent publications go this way by examining, for instance, how the rule of law conditionality on EU funds-as proposed by the European Commission 2018-should be organised in order to yield the envisioned results (Blauberger and van Hüllen 2020; Neuwahl and Kovacs 2020). So far, most of these studies rely on theoretical approaches of the literature on EU enlargement and Europeanisation.

A fruitful approach to complement this evolving body of literature could also be to draw interregional comparisons and to borrow from neighbouring research areas by studying patterns of conflict accommodation in heterogeneous federations (e.g. Canada, Brazil, Australia). How do these cases manage to integrate territorial units by acknowledging their societal and cultural differences on the one hand and insisting on stable foundational principles of the interrelationship on the other hand? Existing multi-level systems, like federations, have established a variety of frameworks to balance legal unity and diversity and they provide insights on possible constitutional solutions (e.g. Bednar et al. 1999; Benz and Broschek 2013; Burgess 2006; Moreno and Colino 2010; Kymlicka 2007). While it is clear that the European Union is not a traditional state (Schmidt 1999, p. 19), learning from other political entities on an abstract level is always possible and could potentially provide fresh insights.

Secondly, future research should acknowledge that judicial reasoning starts from a given norm while democratic reasoning starts from the people establishing a norm. The vague constitutionalisation of certain EU norms as a compromise between the will to codify the fundamentals and the lack of will to agree on what they mean has not proved to be an equilibrium solution. When EU treaty provisions remain undetermined because governments cannot agree at the negotiating table, they usually rely on the European judiciary (Alter 2001; Grimm 2015; Schmidt 2017). The European Commission is currently also resorting to this strategy. To clarify the meaning of the EU's foundational principles, it draws on case law (European Commission 2014) and refers rule of law-related cases to the Court (European Commission 2019). This is problematic since the 
selective self-expansion of competences by case law has already damaged the acceptance of court rulings (for an overview, see De Waele 2010). Moreover, it becomes questionable if the CJEU's jurisprudence will be accepted and complied when the court increasingly decides on politically sensitive and contested issues (Blauberger and Martinsen 2020).

It seems that the old conflict between the core logic of constitutionalism and the logic of democracy-some theorised ways to reconcile them (Habermas 2001) - is still clearly visible and increasingly fuelled by populists claiming to be exclusively dedicated to the will of the people. Against this background, future theorising should reflect on how to initiate and uphold a broad constitutional debate on the meaning of the EU constitutional principles and its multi-level government structure. A discussion is also needed on how inclusive such a constitutional debate should and can be. On the one hand, some have criticised the EU's constitutional process, which so far has failed to "place the citizen at the center" (Aziz 2009, p. 282). On the other hand, we know that inclusiveness, while it is to be welcomed in normative terms, potentially limits the scope for agreement.

Around the negotiations of the Convention on the Future of Europe, a body comprising representatives of member and candidate states (see, e.g., Wilga 2008), many interesting works on constitutional debates have been published (e.g. Closa and Fossum 2004; Landfried 2006; Maurer 2003; more general Eriksen et al. 2004). Along with studies of negotiations and deliberative aspects, some also promoted a societal approach to assess the emergence and role of constitutional and sociocultural norms (Wiener 2003). These studies should be reviewed in the light of current developments, continued and developed further by reflecting on how to enable and strengthen the communication between European citizens of different member states and their communication with EU officials, e.g. by deliberative fora beyond day-to-day politics.

More generally, such research also needs to address the following questions: To what extent should and ought critics be heard? Where to draw the line between those questions that necessarily have to be the subject of political dissensus to secure the very logic of democracy and those constitutional rules that determine the political order's existence, equality and freedom and therefore shall remain uncontroversial (Fraenkel 1974, pp. 184ff.)? While dispute is vital for any democracy understood as the dynamic, temporally bound choice of best political solutions by the people, the undisputable rules must rest on a basic societal agreement 
(Dahl 1993, p. 133); they are no longer disputed because the struggles surrounding them were settled by political agreement (and not because there is an authoritative decision to do so).

The contributions of the fourth part of the book support these reflections. They remind us to regularly check whether our conceptual repertoire still adequately covers the subject under study. As highlighted in the chapters, illiberal trends do not automatically result in fully fledged autocracies. Yet, some countries investigated in the volume can no longer be classified as liberal democracies. This brings us back to earlier studies on regime change in the region and the elephant in the room. As already indicated, we think that research on the interrelationship between post1989 system change and European integration, on their long-term effects and on their reassessment today, is worth being re-strengthened. The idea of a quasi-linear development towards liberal democracy also has to be adjusted to empirical reality (see Buštíková and Guasti 2019).

While illiberal trends are not just East Central European phenomena, the chapters have shown that their particular form, the arguments surrounding them and the structure of support vary and are often rooted in national contexts. Questions to be addressed in future research therefore could be if universalist democratic beliefs, proactive bottom-up civic engagement, public debate, vital parliamentarism and a reflexive division of powers actually have ever been as relevant to political practice as envisioned by the model of liberal democracy (cf. Guasti and Mansfeldová 2018). As emphasised in Chapter 1 , there have been critical studies on the state of democracy in East Central Europe, but due to the euphoria about Eastern enlargement, they received little attention (see, for instance, Greskovits 2007). In the light of current developments, it seems worthwhile to reassess older evaluations of the state of democracy in the region. Such an endeavour can also contribute to the renewed academic debate about the set of indicators for measuring the regime type or modes of gathering data properly (e.g. Coppedge and Altman 2011; Alexander et al. 2012; Knutsen 2010; Møller and Skaaning 2011) which also resulted in constructing new indices, like V-Dem. In line with recent publications, the findings of this volume suggest that those indices should place greater emphasis on the role of citizens (Mayne and Geissel 2018).

In order to address the links between post-1989 regime change and European integration and to further investigate their reverberations on current developments in the region, one should analyse how actors reassess domestic liberalisation, the EU accession negotiations and the EU 
membership today and how this influences their political action. Illiberal party programmes in ECE can, inter alia, be attributed to disappointment with former governments' decisions or mistakes during transformation. Illiberal actors might also be motivated to correct past decisions against the will of the administration, courts and beneficiaries of former decisions. Favourable privatisation deals or the accumulation of positions in public administration (Grzymała-Busse 2003), for instance, are not just imagined agitation, but indisputable facts. Also, as enlargement was "not without domestic costs", Grzymała-Busse and Innes had already concluded in 2003 that it "is this perception that "there is no alternative" that also underpins the rise of anti-EU politicians who substitute populism in lieu of substantial debate over ideology or policy in the new democracies of East Central Europe. In short, the demands of enlargement have both constrained responsive and accountable party competition and, as the character of enlargement became apparent, encouraged populists and demagogues" (Grzymała-Busse and Innes 2003, p. 64). Recent studies on the region have already taken up these ideas and advanced them in a promising way (Krastev and Holmes 2020).

When politicians follow an agenda of renationalisation and speak of "regaining democracy from corrupt elites" and courts perceived as having dominated the transformation process (Miklóssy 2018), or when they publicly argue that they intend to clean the branches of government from clientelistic and corrupt networks, this refers to a reassessment of former policies that can perhaps explain why citizens support them irrespectively of how liberal or illiberal their action is. As studies taking up these ideas would necessarily go beyond analysing the interplay of political decisionmakers in the executive and legislative arena, they would benefit from the cooperation of scholars from various disciplines and with area expertise.

\section{OutLOOK}

The present chapter summarised the main findings on illiberal trends and anti-EU politics in East Central Europe. We highlighted selected key findings and suggested paths for future research. It has become clear that the instruments to secure liberal democracy and compliance within the EU require modification. Such modifications should be based on both conceptual work and area expertise. A deepened understanding of national specificities will help to understand why certain tools-even if legally valid-work differently than originally envisaged and to adapt 
them accordingly. Against this backdrop, we underlined the need for more research on the emergence of illiberal and EU-related attitudes, programmes and rhetoric and on unresolved transformation and enlargement conflicts in East Central Europe. On a more general level, a question for further reflection should also be how much conflict and diversity of views is necessary for a vibrant (European) democracy and where to draw the boundaries between disputable and indisputable issues.

As the chapters in this volume have shown, bringing societies back in and studying political developments from various disciplines and theoretical angles is a promising approach to achieve a comprehensive analysis of current challenges in Europe. To provide a more realistic impression of citizens' position-building, cognitive maps, party-voters linkages and decision-making processes on EU- and democracy-related topics in the EU multi-level system, future analyses should also move beyond the highly politicised conflict issues. The proposed topics for future research reflect and support the recent pluralisation of European Union Studies (Kreppel 2012). Broadening the questions and integrating domestic and area studies will require scholars to link different strands of research to make the best of their diversity for theory-building.

\section{REFERENCES}

Ágh, Attila. 2002. Public Sector Reforms, Institutional Design and Strategy for Good Governance in East Central Europe. Studies in East European Thought 53 (3): 233-255.

Alexander, A., R. Inglehart, and C. Welzel. 2012. Measuring Effective Democracy: A Defense. International Political Science Review 33: 41-62.

Alter, Karen J. 2001. Establishing the Supremacy of European Law: The Making of an International Rule of Law in Europe. Oxford: Oxford University Press.

Aziz, Mariam. 2009. Implementation as the Test Case of European Union Citizenship. Columbia Law Journal of European Law 15: 281-298.

Bauer, M.W., and S. Becker. 2020. Democratic Backsliding, Populism, and Public Administration. Perspectives on Public Management and Governance 3 (1): $19-31$.

Bednar, Jenna, W.N. Jr. Eskridge, and J. Ferejohn. 1999. A Political Theory of Federalism. Washington, DC: World Bank.

Benz, Artur, and J. Broschek (eds.). 2013. Federal Dynamics: Continuity, Change, and the Varieties of Federalism. Oxford: Oxford University Press. 
Bernhagen, P., and M. Marsh. 2007. Voting and Protesting: Explaining Citizen Participation in Old and New European Democracies. Democratization 14 (1): 44-72.

Blauberger, M., and D.R. Kelemen. 2016. Can Courts Rescue National Democracy? Judicial Safeguards Against Democratic Backsliding in the EU. Journal of European Public Policy 24 (3): 321-336.

Blauberger, M., and V. van Hüllen. 2020. Conditionality of EU Funds: An Instrument to Enforce EU Fundamental Values? Journal of European Integration. https://doi.org/10.1080/07036337.2019.1708337.

Blauberger, M., and D.S. Martinsen. 2020. The Court of Justice in Times of Politicisation: 'Law as a Mask and Shield' Revisited. Journal of European Public Policy 27 (3): 382-399.

Böckenförde, Ernst-Wolfgang. 1976. Die Entstehung des Staates als Vorgang der Säkularisation. In Staat, Gesellschaft, Freibeit. Studien zur Staatstheorie und zum Verfassungsrecht, ed. Ernst-Wolfgang Böckenförde, 42-64. Frankfurt am Main: Suhrkamp.

Bos, Ellen, and K. Pócza (eds.). 2014. Rechtssysteme im Donauraum. Vernetzung und Transfer. Baden-Baden: Nomos.

Burgess, Michael. 2006. Comparative Federalism: Theory and Practice. Abingdon and New York: Routledge.

Buštíková, L., and P. Guasti. 2019. The State as a Firm: Understanding the Autocratic Roots of Technocratic Populism. East European Politics and Societies: and Cultures 33 (2): 302-330.

Bustikova, L., and H. Kitschelt. 2009. The Radical Right in Post-Communist Europe: Comparative Perspectives on Legacies and Party Competition. Communist and Post-Communist Studies 42: 459-483.

Closa, Carlos, and J.E. Fossum (eds.). 2004. Deliberative Constitutional Politics in the EU. Oslo: ARENA.

Coppedge, M., and D. Altman. 2011. Conceptualizing and Measuring Democracy: A New Approach. Perspectives on Politics 9 (2): 247-267.

Dahl, Robert A. 1993. A Preface to Democratic Theory. Chicago: University of Chicago Press.

De Waele, Henri. 2010. The Role of the European Court of Justice in the Integration Process: A Contemporary and Normative Assessment. Hanse Law Review: The E-Journal on European, International and Comparative Law 6 (1): 3-26.

de Wilde, Pieter, R. Koopmans, W. Merkel, O. Strijbis, and M. Zürn (eds.). 2019. The Struggle over Borders: Cosmopolitanism and Communitarianism. Cambridge: Cambridge University Press.

Dimitrova, Anna. 2005. Europeanization and Civil Service Reform in Central and Eastern Europe. In The Europeanization of Central and Eastern Europe, ed. 
F. Schimmelfennig and U. Sedelmeier, 71-90. Ithaca, NY: Cornell University Press.

Eriksen, Erik Oddvar, J.E. Fossum, and A.J. Mendez (eds.). 2004. Developing a Constitution for Europe. New York: Routledge.

European Commission. 2014. Annexes to the Communication from the Commission to the European Parliament and the Council: A New EU Framework to Strengthen the Rule of Law (COM 158 final).

European Commission. 2019. Communication from the Commission to the European Parliament and the Council: Further Strengthening the Rule of Law within the Union State of Play and Possible Next Steps (COM 163 final).

Fraenkel, Ernst. 1974. Demokratie und öffentliche Meinung. In Deutschland und die westlichen Demokratien, ed. Ernst Fraenkel, 173-196. Stuttgart: Kohlhammer.

Greskovits, Béla. 2007. Is East-Central Europe Backsliding? Economic Woes and Political Disaffection. Journal of Democracy 18 (4): 40-46.

Grimm, Dieter. 2015. The Democratic Costs of Constitutionalisation: The European Case. European Law Journal 21: 460-473.

Grzymała-Busse, Anna. 2003. Political Competition and the Politicization of the State in East Central Europe. Comparative Political Studies 36 (10): 11231147.

Grzymała-Busse, A., and A. Innes. 2003. Great Expectations: The EU and Domestic Political Competition in East Central Europe. East European Politics and Societies 17 (1): 64-73.

Guasti, Petra, and Z. Mansfeldová (eds.). 2018. Democracy Under Stress: Changing Perspectives on Democracy, Governance and Their Measurement. Prague: Czech Academy of Sciences.

Habermas, Jürgen. 2001. Constitutional Democracy: A Paradoxical Union of Contradictory Principles. Political Theory 29 (6): 766-781.

Havlík, Vlastimil. 2019. Technocratic Populism and Political Illiberalism in Central Europe. Problems of Post-Communism 66 (6): 369-384.

Hurrelmann, A., A. Gora, and A. Wagner. 2015. The Politicization of European Integration: More Than an Elite Affair? Political Studies 63 (1): 43-59.

Jakab, András, and D. Kochenov (eds.). 2017. The Enforcement of EU Law and Values: Ensuring Member States' Compliance. Oxford: Oxford University Press.

Janicek, Karel, M. Scislowska, and D. Gatopoulos. 2019. Legal Opinion: Poland, Hungary, Czechs Broke EU Migrant Law. https://federalnewsnetwork.com/ world-news $/ 2019 / 10 /$ rights-envoy-urges-greece-to-transfer-migrants-to-mai nland/. Accessed 24 April 2020.

Kaltwasser, C.R., and S.M. van Hauwaert. 2020. The Populist Citizen: Empirical Evidence from Europe and Latin America. European Political Science Review 12 (1): 1-18. 
Kitschelt, Herbert. 2003. Diversification and Reconfiguration of Party Systems in Postindustrial Democracies. Bonn: Friedrich-Ebert-Stiftung.

Knutsen, C.H. 2010. Measuring Effective Democracy. International Political Science Review 31: 109-128.

Krastev, Ivan, and S. Holmes. 2020. The Light That Failed: A Reckoning. London: Penguin Books.

Krekó, P., and Z. Enyedi. 2018. Explaining Eastern Europe: Orbán’s Laboratory of Illiberalism. Journal of Democracy 29 (3): 39-51.

Kreppel, Amie. 2012. The Normalization of the European Union. Journal of European Public Policy 19 (5): 635-645.

Kymlicka, Will. 2007. Ethnocultural Diversity in a Liberal State: Making Sense of the Canadian Model(s). In Belonging? Diversity, Recognition and Shared Citizenship in Canada, ed. K. Banting, T.J. Courchene and L.F. Seidle, vol. 3, 39-86. Montreal: Institute for Research on Public Policy.

Landfried, Christine. 2006. Difference as a Potential for European Constitution Making. European Law Journal 12 (6): 764-787.

Linz, Juan J., and A. Stepan. 1996. Problems of Democratic Transition and Consolidation: Southern Europe, South America, and Post-Communist Europe. Baltimore, MD: Johns Hopkins University Press.

Manow, Philip. 2019. Die Politische Ökonomie des Populismus. Berlin: Suhrkamp. Maurer, Andreas. 2003. Less Bargaining-More Deliberation: The Convention Method for Enhancing EU Democracy. International Politics and Society 1 : 167-190.

Mayne, Q., and B. Geissel. 2018. Good Democracies Need “Good" Citizens: Citizen Dispositions and the Study of Democratic Quality. In Democracy Under Stress: Changing Perspectives on Democracy, Governance and Their Measurement, ed. P. Guasti and Z. Mansfeldová, 141-160. Prague: Czech Academy of Sciences.

Merkel, Wolfgang. 1998. The Consolidation of Post-Autocratic Democracies: A Multi-Level Model. Democratization 5 (3): 33-67.

Meyer-Sahling, Jan-Hinrik. 2009. Varieties of Legacies: A Critical Review of Legacy Explanations of Public Administration Reform in East Central Europe. International Review of Administrative Sciences 75 (3): 509-528.

Miklóssy, Katalin. 2018. Lacking Rule of Law in the Lawyers' Regime in Hungary. Journal of Contemporary European Studies 26 (3): 270-284.

Ministry of Justice. 2020. Hungary Continues to Reject Migrant Quotas. https://www.kormany.hu/en/ministry-of-justice/news/hungary-continuesto-reject-migrant-quotas. Accessed 2 April 2020.

Møller, J., and S.-E. Skaaning. 2011. Requisites of Democracy: Conceptualization, Measurement and Explanation. London: Routledge.

Moreno, Luis, and C. Colino (eds.). 2010. Diversity and Unity in Federal Countries. Montreal: McGill-Queen's University Press. 
Mos, Martijn. 2020. Ambiguity and Interpretive Politics in the Crisis of European Values: Evidence from Hungary. East European Politics 36 (2): 267-287.

Neuwahl, N., and C. Kovacs. 2020. Hungary and the EU's Rule of Law Protection. Journal of European Integration. https://doi.org/10.1080/07036337. 2019.1708337.

Offe, Claus. 1994. Capitalism by Democratic Design? Democratic Theory Facing the Triple Transition in Central and Eastern Europe. In Studies in Contemporary Economics: The Political Economy of Transformation, ed. Hans J. Wagener, 25-43. Heidelberg: Springer.

Pickel, Gert. 2009. Revitalization of Religiosity as Normalization? Romania in European Comparative Perspective. Studia Universitatis Babeş-Bolyai Sociologia Issue 2 (December): 9-36.

Pospíšil, Ivo. 2020. Activist Constitutional Court as Utility Tool for Correcting Politics: Structure, Composition and Case-Law. In Czech Democracy in Crisis, ed. A. Lorenz and Hana Formánková, 133-155. Basingstoke: Palgrave.

Prague Morning. 2020. Czech Politicians Call EU Ruling on Migrant Quotas “Irrelevant”. https://www.praguemorning.cz/czech-politicians-calleu-ruling-on-migrant-quotas-irrelevant/. Accessed 3 April 2020.

Schmidt, Susanne K. 2017. Extending Citizenship Rights and Losing it All: Brexit and the Perils of 'Over-Constitutionalisation'. In Questioning EU Citizenship: Judges and the Limits of Free Movement and Solidarity in the EU, ed. Daniel Thym, 17-36. Oxford: Hart Publishing.

Schmidt, Vivien. 1999. European "Federalism" and Its Encroachments in National Institutions. Publius: The Journal of Federalism 29 (1): 19-44.

Stevis-Gridneff, M., and M. Pronczuk. 2020. E.U. Court Rules 3 Countries Violated Deal on Refugee Quotas. New York Times. https://www.nytimes. com/2020/04/02/world/europe/european-court-refugees-hungary-pol and-czech-republic.html. Accessed 24 April 2020.

Thym, Daniel (ed.). 2017. Questioning EU Citizenship: Judges and the Limits of Free Movement and Solidarity in the EU. Oxford: Hart Publishing.

Tilles, David. 2020. We Stopped EU “Imposing Foreign Culture of Islam on Us", Says Polish Minister Following ECJ Ruling. https://notesfrompoland.com/ 2020/04/06/polish-minister-accuses-eu-of-trying-to-impose-foreign-cultureof-islam-on-us-following-ecj-ruling/. Accessed 24 April 2020.

TVN24. 2020. CJEU: Poland, Czech Rep., Hungary Broke EU Law by Not Hosting Refugees. https://tvn24.pl/tvn24-news-in-english/cjeu-polandczech-rep-hungary-broke-eu-law-by-not-hosting-refugees-4535064. Accessed 24 April 2020.

Vachudova, Milada A. 2019. From Competition to Polarization in Central Europe: How Populists Change Party Systems and the European Union. Polity 51 (4): 689-706. 
Varga, Judit. 2020. \#EU Compulsory Relocation System.... https://twitter.com/ JuditVarga_EU/status/1245653581262286848.

Wiener, Antje. 2003. Editorial: Evolving Norms of Constitutionalism. European Law Journal 9 (1): 1-13.

Wilga, Maciej. 2008. Poland and the Constitutional Treaty: A Short Story About a 'Square Root'? In The Rise and Fall of the EU's Constitutional Treaty, ed. Finn Laursen, 225-248. Leiden: Martinus Nijhoff Publishers.

Zubek, R., and K. Goetz. 2010. Performing to Type? How State Institutions Matter in East Central Europe. Journal of Public Policy 30 (1): 1-22.

Open Access This chapter is licensed under the terms of the Creative Commons Attribution 4.0 International License (http://creativecommons.org/licenses/ by $/ 4.0 /)$, which permits use, sharing, adaptation, distribution and reproduction in any medium or format, as long as you give appropriate credit to the original author(s) and the source, provide a link to the Creative Commons license and indicate if changes were made.

The images or other third party material in this chapter are included in the chapter's Creative Commons license, unless indicated otherwise in a credit line to the material. If material is not included in the chapter's Creative Commons license and your intended use is not permitted by statutory regulation or exceeds the permitted use, you will need to obtain permission directly from the copyright holder.

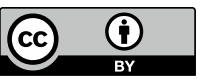

